\title{
Comparative Osteometric Study of Some Selected Bones of Local Domestic Turkey
}

\author{
Bello Abdulrahman*1 and Aisha Yusuf1
}

and Guinea Fowl

\author{
'Department of Veterinary Anatomy, Usmanu Danfodiyo University, Sokoto \\ *Corresponding author: Bello, Abdulrahman, Department of Veterinary Anatomy, Usmanu Danfodiyo University, Sokoto
}

\section{Abstract}

research was conducted in the Gross section of Veterinary Anatomy laboratory with the aim of preparation and comparing some skeleton bones of local domestic turkey and guinea fowl. Samples were purchased, sacrifice, feather and excess flesh were removed and boiled using water to produce the bones. The duration of process was recorded. Comparative biometry study was conducted on some selected bones (scapular, coracoid, furcular and tibiotarsus) and the bones were mounted using wooden stand, copper wire, and adhesive gum with the aim of enhancing avian teaching. Based on the processes of the research. It was recommended to use plastic materials in production of skeletal models to avoid deterioration of bones for proper teaching in veterinary anatomy.

Keywords: Local domestic turkey, Guinea fowl, Scapular, Coracoid, Furcular, Tibiotarsus

\section{Introduction}

Avian also known as birds are a group of endothermic vertebrates whose characteristics include feathers, toothless beaked jaws, laying of hard-shelled eggs, four chambered hearts and a strong but lightweight skeleton. Avian live all around the world and vary in size with the smallest being the bee hummingbird with a height of $2 \mathrm{~cm}$ and the largest being the ostrich with a height of $2.75 \mathrm{~m}$. There are approximately ten thousand species $(10,000)$ of birds around the whole world [1]. Chickens and turkeys are the most commonly reared avian because of their high economical and health importance to humans [1].

Osteology is the study of the structures and function of the skeleton and bony structures. It is the scientific study of bones it is a sub discipline of anatomy. Bones make up a skeleton; they are designed to provide adequate strength with minimal mass or weight. Based on development, we have Endochondral and Intramembranous bones. Based on location, are classified based on Axial and Appendicular skeleton, while based on shape, we have long bones short bones, flat bones, irregular bones and sesamoid bones.

The Skeleton is defined as the frame work that supports, protects and forecasts the body structure of an organism [2]. The skeleton can be classified into two based on their location as internal and external skeletons. Skeleton come in a number of forms, each suited for a particular set of lifestyles and environment. Skeletons can be rigid, semirigid or soft. vertebrates have internal skeleton called bony skeleton, which consist mainly of calcified bone tissues The internal skeletons are hard mineralized structures that are located within the muscles of the organisms. The internal skeletons provide protection, support and enable movement of the muscle. The external skeletons are hard encasements on the surface of organisms, insects and animals. Examples of external skeleton include shells of crabs and insects. This external skeleton provides defense against predators, allows for movement and supports the body [1].

The skeleton is composed of bones, cartilages and ligaments. Skeletons of animals and birds are the basic need of the veterinary study, especially for the veterinary gross anatomy [3]. These skeletons are necessary for research ranging from phylogenic investigations to age and growth analyses to functional morphology [4] and essential tools for the study of systematic, biomechanics, evolutionary morphology \& adaptation, paleontology and identification of animal remains from archeological sites. It is the backbone of the study of many pathological conditions. It is the backbone of the study of many pathological conditions 
Turkey is an avian specie (Meleagris gallopavo) which is a large gallinaceous bird of the family Meleagridae, which is a native of North America. There is only one turkey breed but there are many turkey species. The popular varieties that have attained commercial importance in different parts of the world are the Broad Breasted, Large White and the Broad Breasted Bronze. Other breeds are the White Holland, the Beltsville Small White, the Black, the Bourbon Red and the Narrangansell [5]. Male turkeys have a distinctive fleshy wattle or protuberance that hangs from the top of the beak called a (snood). They are among the largest birds in their ranges. As in many Galliformes, the males are larger and much more colorful than females. Turkeys are classed in the family phasianidae in the taxonomic order of meleagris ocellata. The meleagris is the only extent genus in the subfamily meleagrididae, but now subsumed within the family phasianidae. The two main species are distributed thus: meleagris gallopavo also known as domestic turkey or wild turkey are found in forests of North America, Throughout the Midwest and in southern Canada meleagris ocellata also known as ocellated turkey are found in the forests of the Yucatan peninsula [6]. Turkeys are reared using a domesticated system in Europe, a semi domesticated system and free-range system in Africa. Turkeys have an estimated population of over seven million turkey's worldwide [6].

Guinea fowls are the largest living bird reaching over $200 \mathrm{~kg}$ body weight and $2.7 \mathrm{~cm}$ in height. It is classified under Ratites, which are large ground dwelling, flightless birds such as rhea, emu, cassowary, and kiwi. Guinea fowls also known as original fowl are birds of the family numididae in the order Galliformes. They are endemic to Africa and rank among the oldest of the gallinaceous birds. Phylogenetically, they branch off from the core Galliformes after the cracidae and before the odontophoridae, which is an Eocene fossil lineage, telecrex. [7]. The insect eating, ground nesting birds of this family resemble partridges, but with featherless heads, though both members of the genus guttera have a distinctive black crest, and the vulturine Guinea fowl has a downy brown patch on the nape. Most species of Guinea fowl have a dark grey or blackish plumage, with dense white spot, but both members of the genus angulates lack the spots.

Skeleton of animals and birds are the basic need of the veterinary study, especially for the veterinary gross anatomy [3]. These skeletons are necessary for research ranging from phylogenic investigations to age and growth analyses to functional morphology [4] and essential tools for the study of systematic, biomechanics, evolutionary morphology and adaptation, paleontology and identification of animal remains from archeological sites. It is the backbone of the study of many pathological conditions. It is the study of many pathological conditions [4]. This work is done to make available the morphometrical studies of the bones of an adult turkey and guinea fowl for analysis and comparative studies in the study of the skeletal anatomy of bones. The aim of the research is to compare Morphological and biometric parameters of some selected bones of clinical importance in an adult local domestic turkey and guinea fowl

\section{Materials and Methodology}

\section{Study Area}

The city of Sokoto is located in the extreme North West of Nigeria near to the confluence of river Sokoto and River Rima. Sokoto has a land size of $25,973 \mathrm{~km} 2$ with population of 3,702,676 people. Sokoto state shares a boarder with Niger Republic, Zamfara state and Kebbi State.

The northwestern state was created in 1967, seven years after Nigeria got her independence from the Britain. It was later split into Sokoto and Niger and Sokoto was then split into Kebbi and Zamfara in 1991 and 1996 respectively. The state has an annual average temperature of 28.3, making it one of the hottest cities in the world, however the maximum daytime temperatures are generally under $40{ }^{\circ} \mathrm{C}$ most of the year although it could go above. Sokoto currently is the second largest producer of livestock in Nigeria. With an estimate of 1.18 million cattle, 2.90 million goats, 1.90 million sheep, 2.0 million chickens and turkeys, 45,000 camels, 34,532 horses and 51,388 donkeys.

\section{Sample Collection and Processing}

Ten (10) fully grown and matured turkey of age 2-3 years and ten (10) fully-grown matured guinea fowl of age 2-3 years were selected based on their history, physical appearances and lack of any skeletal abnormalities. These breeds were all obtain from the local houses in Sokoto town. It was ensured that there were no congenital deformities and scars present in the samples. The avian were later processed for biometric comparative analysis in the gross Anatomy Laboratory of the Faculty of Veterinary Medicine at Usmanu Danfodiyo University Sokoto, Sokoto State.

The birds were then sacrificed by the severing of the jugular veins; great care was taken so as not to damage the bones of the neck. They were then de-feathered by emancipation in hot water and the feathers were then plucked out. The internal organs of the birds were gently removed after de-feathering had being done. The birds were then de-fleshed using a sharp scalpel blade, carefully

Citation: Bello Abdulrahman* and Aisha Yusuf. Comparative Osteometric Study of Some Selected Bones of Local Domestic Turkey and Guinea Fowl

Op Acc J Bio Sci \& Res 7(1)-2021.

DOI: $10.46718 / J B G S R .2021 .07 .000182$ 
Table 1: Comparative Biometric Data of Tibiotarsus between Turkey and Guinea Fowl.

\begin{tabular}{|c|c|c|c|c|}
\hline Parameter & Turkey Left & Turkey Right & Guinea Fowl Left & Guinea Fowl Right \\
\hline A & 28.5 & 29 & 6.5 & 7 \\
\hline B & 1.53 & 1.55 & 0.9 & 0.92 \\
\hline C & 4.1 & 4.3 & 2.4 & 2.6 \\
\hline D & 1.9 & 2 & 1.25 & 1.4 \\
\hline E & 0.95 & 1 & 0.5 & 12.55 \\
\hline F & 20 & 20.6 & 12.5 & 2.9 \\
\hline G & 4.5 & 4.65 & 2.85 & 2.75 \\
\hline H & 4.2 & 4.3 & 2.7 & 10.6 \\
\hline I & 17.2 & 17.4 & 10.3 & 2.7 \\
\hline J & 4.1 & 4.2 & 2.4 & 2 \\
\hline
\end{tabular}

Keys: - $A=$ Weight of tibio tarsus; $B=$ Distance from the medial to lateral condyle; $C=$ Circumference of midshaft; $D=D i s t a n c e$ from

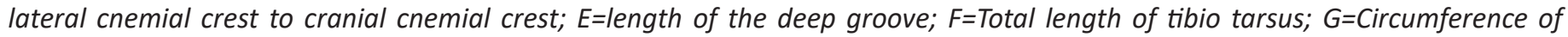
proximal $1 / 3$ of the tibio tarsus; $\mathrm{H}=$ Circumference of distal $1 / 3$ of the tibio tarsus; I=Distance from nutrient foramen to lateral condyle; J=Length of the sloping crest

Table 2: Comparative Biometric Data of Scapula between Turkey and Guinea Fowl.

\begin{tabular}{|c|c|c|c|c|}
\hline Parameter & Turkey Left & Turkey Right & G/Fowl Left & G/ Fowl Right \\
\hline A & 4 & 4 & 1 & 1.5 \\
\hline B & 12.5 & 12.7 & 8.2 & 8.25 \\
\hline C & 0.8 & 0.85 & ABSENT & ABSENT \\
\hline D & 7.9 & 8.1 & 6 & 6.1 \\
\hline E & 3.45 & 3.5 & 2.2 & 2.24 \\
\hline F & 1.48 & 1.5 & 1.05 \\
\hline G & 4.2 & 4.3 & 1.9 & 2 \\
\hline H & 2.65 & 2.7 & 1.27 & 1.3 \\
\hline I & 0.32 & 0.35 & 0.18 & 0.21 \\
\hline
\end{tabular}

Keys: - $A=$ Weight of the scapula; $B=$ Total length of the scapula; $C=$ Length of the deep pneumatic foramen; $D=$ Length from the scapular tubercle to the cranial part of the scapular; $E=L$ Length from the scapular tubercle to the cranial part of the scapular;

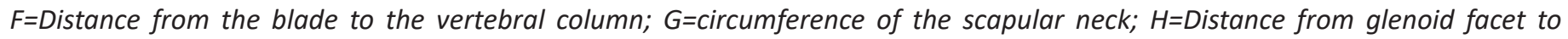
acromion; I=Width of the scapular neck

Table 3: Comparative Biometric Data of Coracoid between Turkey and Guinea Fowl.

\begin{tabular}{|c|c|c|c|c|}
\hline Parameter & Turkey Left & Turkey Right & Guinea Fowl Left & Guinea Fowl Right \\
\hline A & 6.5 & 6.5 & 1.1 & 1.1 \\
\hline B & 1.1 & 1.4 & 0.75 & 0.9 \\
\hline C & 1.3 & 1.6 & ABSENT & ABSENT \\
\hline D & 2.35 & 2.4 & 1.06 & 1.1 \\
\hline E & 0.6 & 0.7 & 0.4 & 0.55 \\
\hline F & 4.4 & 4.9 & ABSENT & ABSENT \\
\hline G & 9.45 & 9.6 & 5.8 & 5.99 \\
\hline
\end{tabular}

Citation: Bello Abdulrahman* and Aisha Yusuf. Comparative Osteometric Study of Some Selected Bones of Local Domestic Turkey and Guinea Fowl 
Keys: - $A=$ Weight of the coracoids; $B=$ Length of the triosseal canal; $C=$ Length of the deep pneumatic foramen; $D=D i s t a n c e$ from lateral condyle to medial condyle; E=Length of the sternal facet; F=Distance from triosseal canal to deep pneumatic foramen (proximal part); G=Total length of the coracoid

Table 4: Comparative Biometric Data of Furcular between Turkey and Guinea Fowl.

\begin{tabular}{|c|c|c|c|c|}
\hline Parameter & Turkey Left & Turkey Right & Guinea Fowl Left & Guinea Fowl Right \\
\hline A & 2 & 1 & & \\
\hline B & 5.4 & 2.2 & & \\
\hline C & 9.85 & 5.4 & & \\
\hline D & 9.7 & 5.6 & & \\
\hline
\end{tabular}

Keys: $-A=$ Weight of the furcular; $B=$ Distance between right and left clavicle; $C=L e n g t h$ of right clavicle; $D=L e n g t h$ of left clavicle Table 5: Statistical Analysis of Tibio Tarsus of Both Turkey and Guinea Fowl.

\begin{tabular}{|c|c|c|c|c|c|c|}
\hline Parameter & Turkey Right & $\begin{array}{c}\text { Guinea Fowl } \\
\text { Right }\end{array}$ & Sem & Turkey Left & $\begin{array}{c}\text { Guinea Fowl } \\
\text { Left }\end{array}$ & Sem \\
\hline $\mathrm{A}$ & 29.03 & 7 & 4.93 & 28.53 & 6.5 & 4.93 \\
\hline$B$ & 4.23 & 2.6 & 0.39 & 4.1 & 2.4 & 0.38 \\
\hline $\mathrm{C}$ & 1.55 & 0.92 & 0.14 & 1.53 & 0.9 & 0.14 \\
\hline$D$ & 2 & 1.4 & 0.19 & 1.9 & 1.25 & 0.15 \\
\hline E & 1 & 0.6 & 0.12 & 0.95 & 0.5 & 0.12 \\
\hline $\mathrm{F}$ & 20.6 & 12.6 & 1.8 & 20 & 12.55 & 1.72 \\
\hline G & 20.6 & 12.6 & 1.8 & 20 & 12.5 & 1.72 \\
\hline $\mathrm{H}$ & 20.6 & 12.6 & 1.8 & 20 & 12.5 & 1.72 \\
\hline I & 17.4 & 10.6 & 1.52 & 17.2 & 10.3 & 1.54 \\
\hline J & 4.2 & 2.67 & 0.35 & 4.1 & 2.43 & 0.37 \\
\hline
\end{tabular}

Keys:- $A=$ Weight of tibio tarsus; $B=$ Circumference of midshaft; $C=$ Distance from medial to lateral condyle; $D=$ Distance from lateral cnemial crest to cranial cnemial crest; $E=$ Length of deep groove; $F=$ Total length of tibio tarsus; $G=$ Circumference of distal $1 / 3$ of the tibio tarsus; $H=$ Circumference of proximal $1 / 3$ of the tibio tarsus; I = Distance from nutrient foramen; $J=$ Length of sloping crest

Table 6: Statistical Analysis of Scapula of Both Turkey and Guinea Fowl.

\begin{tabular}{|c|c|c|c|c|c|c|}
\hline Parameter & Turkey Right & $\begin{array}{c}\text { Guinea Fowl } \\
\text { Right }\end{array}$ & Sem & Turkey Left & $\begin{array}{c}\text { Guinea Fowl } \\
\text { Left }\end{array}$ & Sem \\
\hline $\mathrm{A}$ & 4 & 1.5 & 0.62 & 4 & 1 & 0.72 \\
\hline B & 12.7 & 8.25 & & 12.5 & 8.2 & \\
\hline $\mathrm{C}$ & 0.85 & \multicolumn{2}{|c|}{ ABSENT } & 0.8 & \multicolumn{2}{|c|}{ ABSENT } \\
\hline D & 3.5 & 2.24 & 0.58 & 3.45 & 2.2 & 0.56 \\
\hline E & 3.5 & 2.24 & 0.58 & 3.45 & 2.2 & 0.56 \\
\hline $\mathrm{F}$ & 1.5 & 1.48 & 0.1 & 1.05 & 1 & 0.11 \\
\hline G & 4.3 & 2 & 0.52 & 4.2 & 1.9 & 0.52 \\
\hline $\mathrm{H}$ & 2.7 & 1.3 & 0.32 & 2.65 & 1.27 & 0.31 \\
\hline $\mathrm{L}$ & 0.35 & 0.21 & 0.05 & 0.32 & 0.2 & 0.4 \\
\hline
\end{tabular}

Citation: Bello Abdulrahman* and Aisha Yusuf. Comparative Osteometric Study of Some Selected Bones of Local Domestic Turkey and Guinea Fowl 
Keys:- $A=$ Weight of scapular; $B=$ Total length of scapula; $C=$ Length of pneumatic foramen; $D=$ Length from scapular tubercle to caudal part of the scapular; $E=$ Length from the scapular tubercle to the cranial part of the scapular; $F=$ Distance from blade to vertebral column; $G$ = Circumference of the scapular neck; $H=$ Distance from glenoid facet to acromion; $I=$ Width of the scapular neck

Table 7: Statistical Analysis of Coracoid Both Turkey and Guinea Fowl.

\begin{tabular}{|c|c|c|c|c|c|c|}
\hline Parameter & Turkey Right & $\begin{array}{c}\text { Guinea Fowl } \\
\text { Right }\end{array}$ & Sem & Turkey Left & $\begin{array}{c}\text { Guinea Fowl } \\
\text { Left }\end{array}$ & Sem \\
\hline A & 6.5 & 1 & 1.23 & 6.5 & 1 & 1.23 \\
\hline B & 1.4 & 0.9 & 0.12 & 1.1 & 0.75 & 0.86 \\
\hline $\mathrm{C}$ & & \multicolumn{2}{|c|}{ ABSENT } & & \multicolumn{2}{|c|}{ ABSENT } \\
\hline$D$ & 2.4 & 1.1 & 0.29 & 2.35 & 1.05 & 0.29 \\
\hline E & 0.7 & 0.55 & 0.05 & 0.6 & 0.4 & 0.06 \\
\hline $\mathrm{F}$ & 4.9 & \multicolumn{2}{|c|}{ ABSENT } & 4.4 & \multicolumn{2}{|c|}{ ABSENT } \\
\hline G & 9.6 & 6 & 0.81 & 2 & 1 & 0.8 \\
\hline
\end{tabular}

Keys:- $A=$ Weight of coracoids; $B=$ Length of the triosseal canal; $C=$ Length of the deep pneumatic foramen; $D=$ Distance from the lateral condyle to medial condyle; $E=$ Length of the sternal facet; $F=$ Distance from triosseal canal to deep pneumatic foramen (proximal part); $G=$ Total length of the coracoid

Table 8: Results from Statistical Analysis of Furcular of Both Turkeys and Guinea Fowl.

\begin{tabular}{|l|l|l|l|}
\hline & & & \\
Parameter & Turkey & Guinea Fowl & Sem \\
\hline A & 2 & 1 & 0.23 \\
\hline B & 5.4 & 2.2 & 0.72 \\
\hline C & 9.9 & 5.4 & 0.99 \\
\hline D & 9.7 & 5.6 & 0.92 \\
\hline
\end{tabular}

Keys:- $A=$ Weight of the furcular; $B=$ Distance between right and left clavicle; $C=$ Length of right clavicle; $D=$ Length of left clavicle

removing the feathers from the thighs, the pectoral muscles and muscles from the wings. The remaining adhering muscles were removed by hot water and maceration technique. The turkey and guinea fowl were then boiled separately and a little of potash was added to help in the loosening of the flesh. The boiling lasted for 45 minutes. After boiling, the flesh of the birds was removed gently using scalpels blades, forceps, knives and hands. The bones were then soaked in water for four days. Great care was taken so as to avoid damage to the bones from boiling.

The bones were then rinsed and washed with detergent and then dried in the open for 3 days. After drying the bones were then treated with bleaching reagents (hydrogen peroxide) so as to prevent them from decaying and to prevent insects from burrowing into them, the bones were soaked in water and hydrogen peroxide solution for four days and then kept out to dry for two days. A biometric study on a comparative study of the turkey and guinea fowl was then carried out by taking certain measurements of selected number of bones of the turkey and guinea fowl using meter rule, digital Vernier caliper, strong white thread, digital weighing balance. The results of this measurements are shown in (Tables 1-8). After taking the measurements the bones were then assembled and the skeleton was mounted.

\section{Materials Used}

After successful separation and processing of bones, the bones were measured and mounted afterwards using the following materials

Citation: Bello Abdulrahman* and Aisha Yusuf. Comparative Osteometric Study of Some Selected Bones of Local Domestic Turkey and Guinea Fowl 
Digital caliper

1. thread

2. Meter rule

3. Digital weighing bal.

4. Top bond

5. Four-min. adhesive glue

6. One-minute super glue

7. Saw dust

8. Scalpel blade

9. Thumb forceps

10. Copper wire

11. Ply wood

12. Wooden rod stand

13. Drilling machine

14. Screw nails.

The digital caliper is a precision instrument that can be used to measure internal and external distances extremely accurately, it is used by sliding the jaw along the main scale, the rectangular plates align and misaligns and the capacitance (the amount of electrical charge) between the plates changes. This sends a signal to a chip within the caliper, which generates the readings shown on the LCD display. Calipers usually give a precision to $0.01 \mathrm{~mm}$ (10 micrometers), or one thousandth of an inch. It has a resolution of $0.1 \mathrm{~mm}$ and accuracy of $0.2 \mathrm{~mm}$. Digital weighing balance also known as beam balance was used to take the weights of the selected bones measured, it is a simple device. The bones were placed on the plate of the weighing balance and the readings were read from the LED display monitor.

Thread and meter rule were used simultaneously. The thread was used in measuring curved and rough areas of the bones and then placed on the meter rule to ascertain the measurement. The meter rule was used in straight bones and bones with few rough and less curved surfaces majorly to determine the length of such bones.

\section{Biometric}

This is the application of statistical data to biological data, it is the measurement and statistical analysis of unique physical and behavioral characteristics. In this study, it involves the statistical analysis between selected bones of an adult turkey and an adult guinea fowl, the use of standard error of mean also known as standard deviation and a software known as statistical analysis system to determine the difference and the accuracy of the measurements taken.

\section{Bones Used}

The bones used for the comparative study in this research work are the

1. Scapula

2. Coracoid

3. Furcular

4. Tibio tarsus

The selected bones were singled out and the various parameters used in the research were marked and used in the measurements carried out. The values gotten from bones of the turkey were compared to the value of bones gotten from that of the guinea fowl. Various instruments were used in the measurements depending on the nature of the bone measured and the expected result required from that parameter.

Landmark The anatomical landmarks used in the study were, for tibio tarsus

\section{Tibio Tarsus}

1. Weight of the tibiotarsus

2. Distance from the medial to the lateral condyle

3. Circumference of the mid shaft

4. Distance from the lateral cnemial crest to the medial cnemial crest

5. Length of the deep groove

6. Total length of the tibio tarsus

7. Circumference of the proximal $1 / 3$ of the tibio tarsus

8. Circumference of the distal $1 / 3$ of the tibio tarsus. Scapula

1. Weight of the scapula

2. Total length of scapula

3. Length of the pneumatic foramen

4. Length from the scapular tubercle to the caudal part of the scapular

Citation: Bello Abdulrahman* and Aisha Yusuf. Comparative Osteometric Study of Some Selected Bones of Local Domestic Turkey and Guinea Fowl 
5. Length from the scapular tubercle to the cranial Furcula part of the scapular

6. Distance from the blade to the vertebral border

7. Circumference of the scapular neck

8. Distance from glenoid facet to acromion

9. Width of scapular neck

\section{Coracoid}

1. Weight of the coracoid

2. Length of the triosseal canal

3. Length of the deep pneumatic foramen

4. Distance from the lateral condyle to the medial condyle

5. Length of the sternal facet

6. Width of mid shaft

7. Distance from triosseal canal to deep pneumatic foramen (proximal part)

8. Total length of the coracoid

1. weight of the furcular

2. distance between right and left clavicle

3. length of right clavicle

4. length of left clavicle

\section{Statistics}

\section{Standard Error of Mean}

The standard error is a statistical term that measures the accuracy with which a sample distribution represents a population by using standard deviation. In statistics, a sample mean deviates from the actual mean of a population this deviation is the standard error of the mean

SAS is a command-driven software package used for statistical analysis and data visualization.

\section{Photograph}

Photograph of the bones and mounted skeleton were taken using Samsung digital camera $16.1 \mathrm{mp}$

Results and Discussion

\section{Gross Observation}

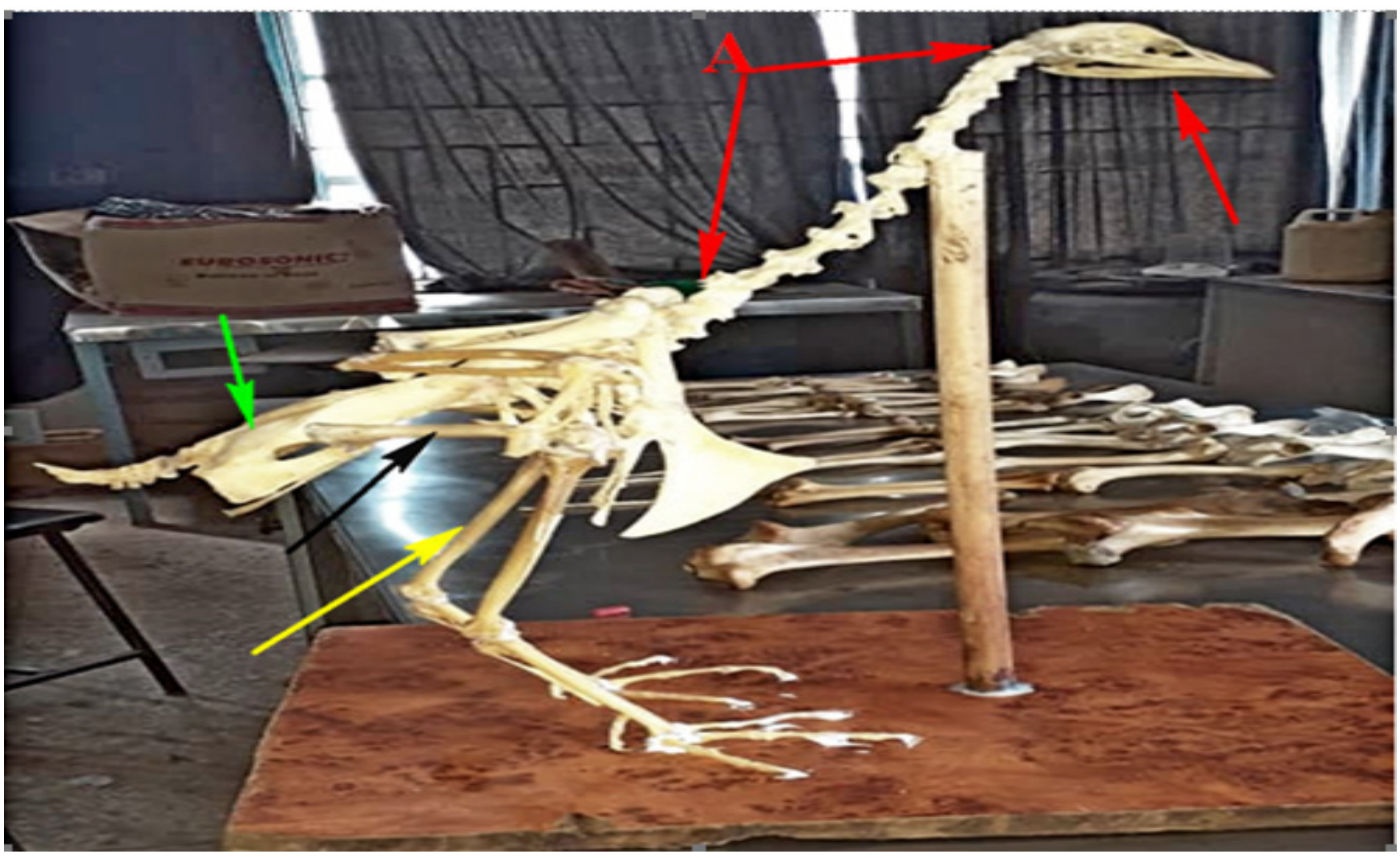

Figure 1: Photograph of mounted skeleton showing the head region (red arrow), neck region (A) synsacrum (green arrow) femur (black arrow) 1and tibiotarsus (yellow arrow).

Citation: Bello Abdulrahman* and Aisha Yusuf. Comparative Osteometric Study of Some Selected Bones of Local Domestic Turkey and Guinea Fowl 

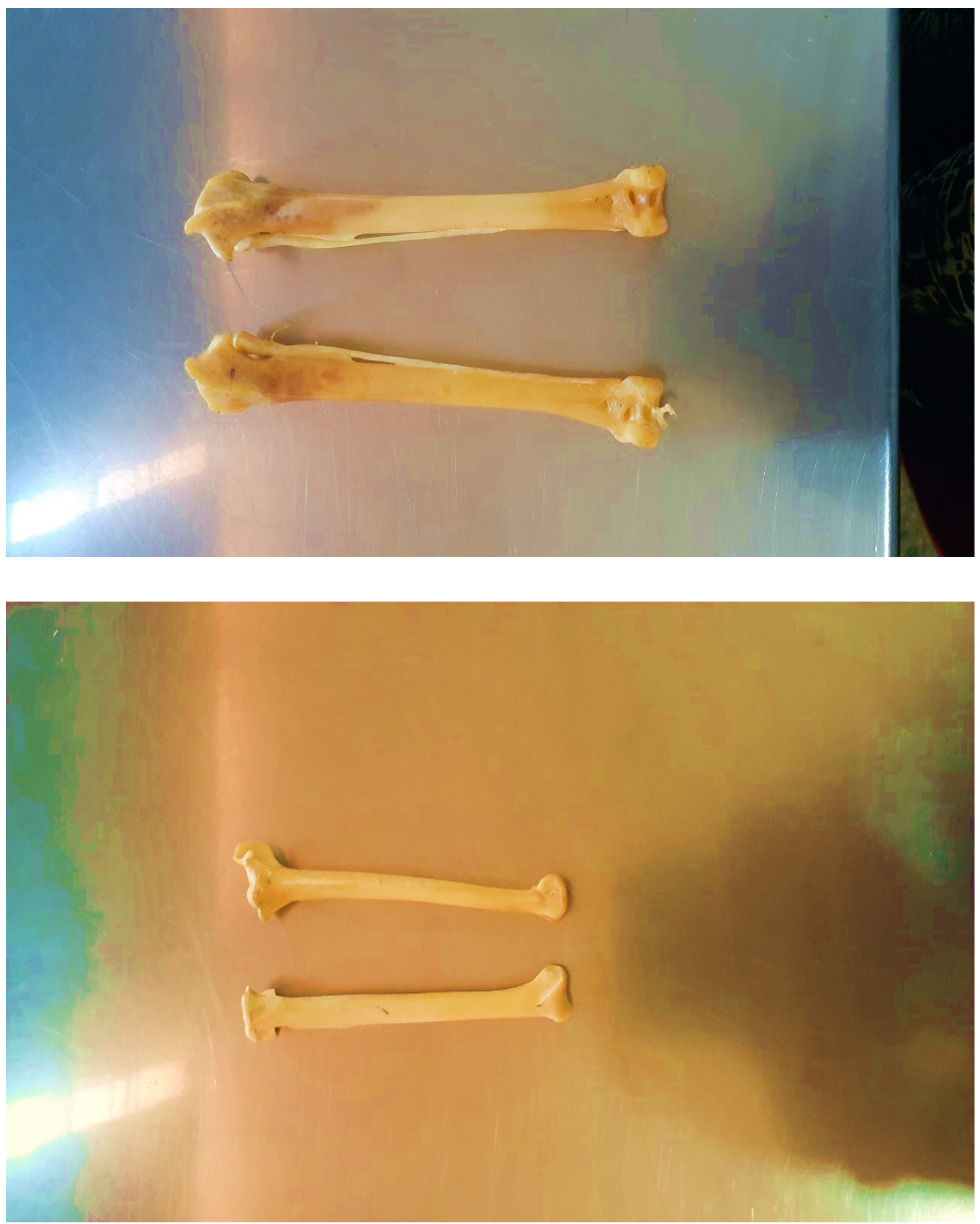

Figure 2: photograph of tibiotarsus of turkey (A) and guineafowl (B)

Citation: Bello Abdulrahman* and Aisha Yusuf. Comparative Osteometric Study of Some Selected Bones of Local Domestic Turkey and Guinea Fowl

Op Acc J Bio Sci \& Res 7(1)-2021. 

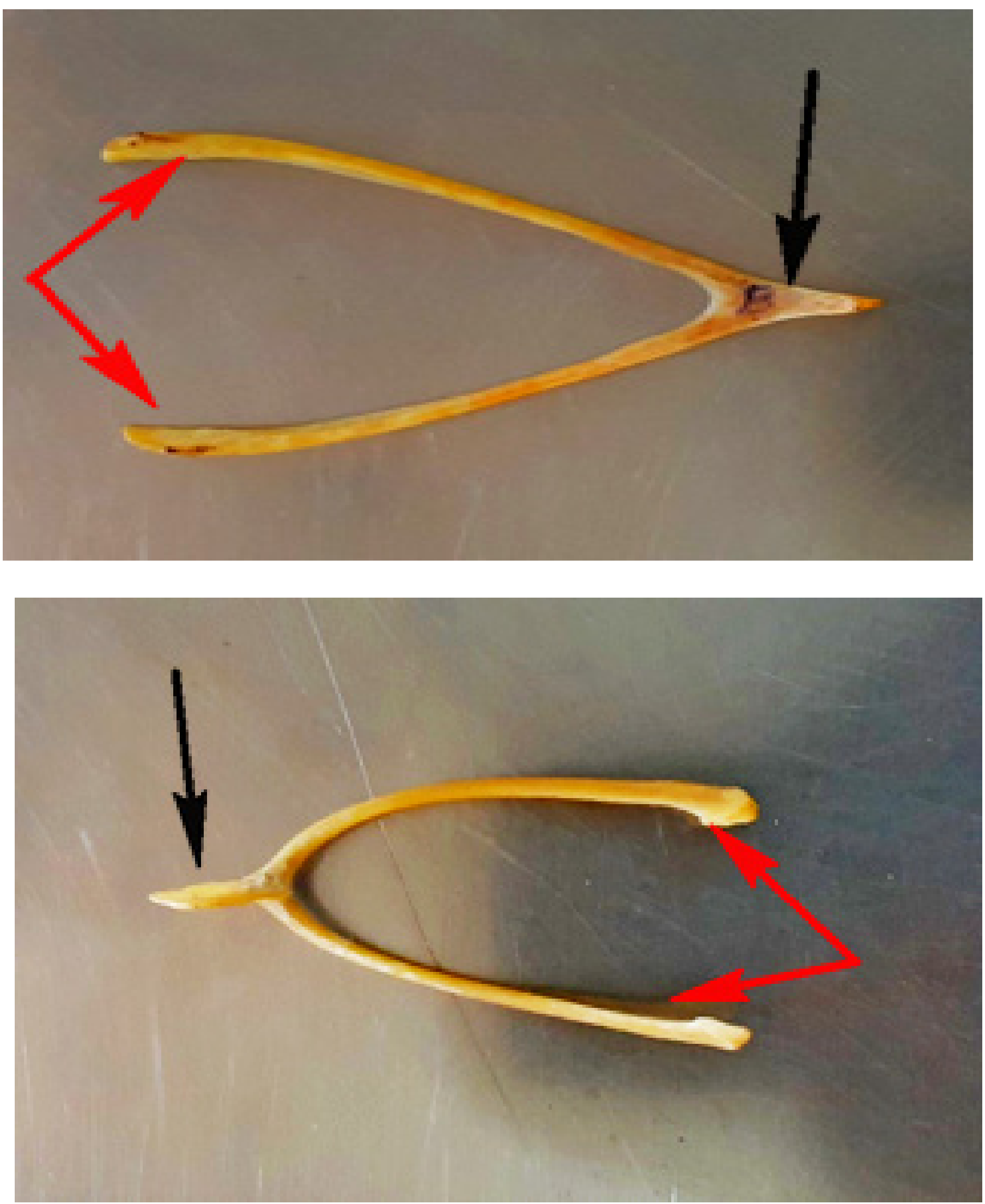

Figure 3: Photograph of furcular of turkey (A) and guinea fowl (B) showing point of attachment of both clavicles (black arrow) and right and left clavicles (red arrow).

Citation: Bello Abdulrahman* and Aisha Yusuf. Comparative Osteometric Study of Some Selected Bones of Local Domestic Turkey and Guinea Fowl

Op Acc J Bio Sci \& Res 7(1)-2021. 

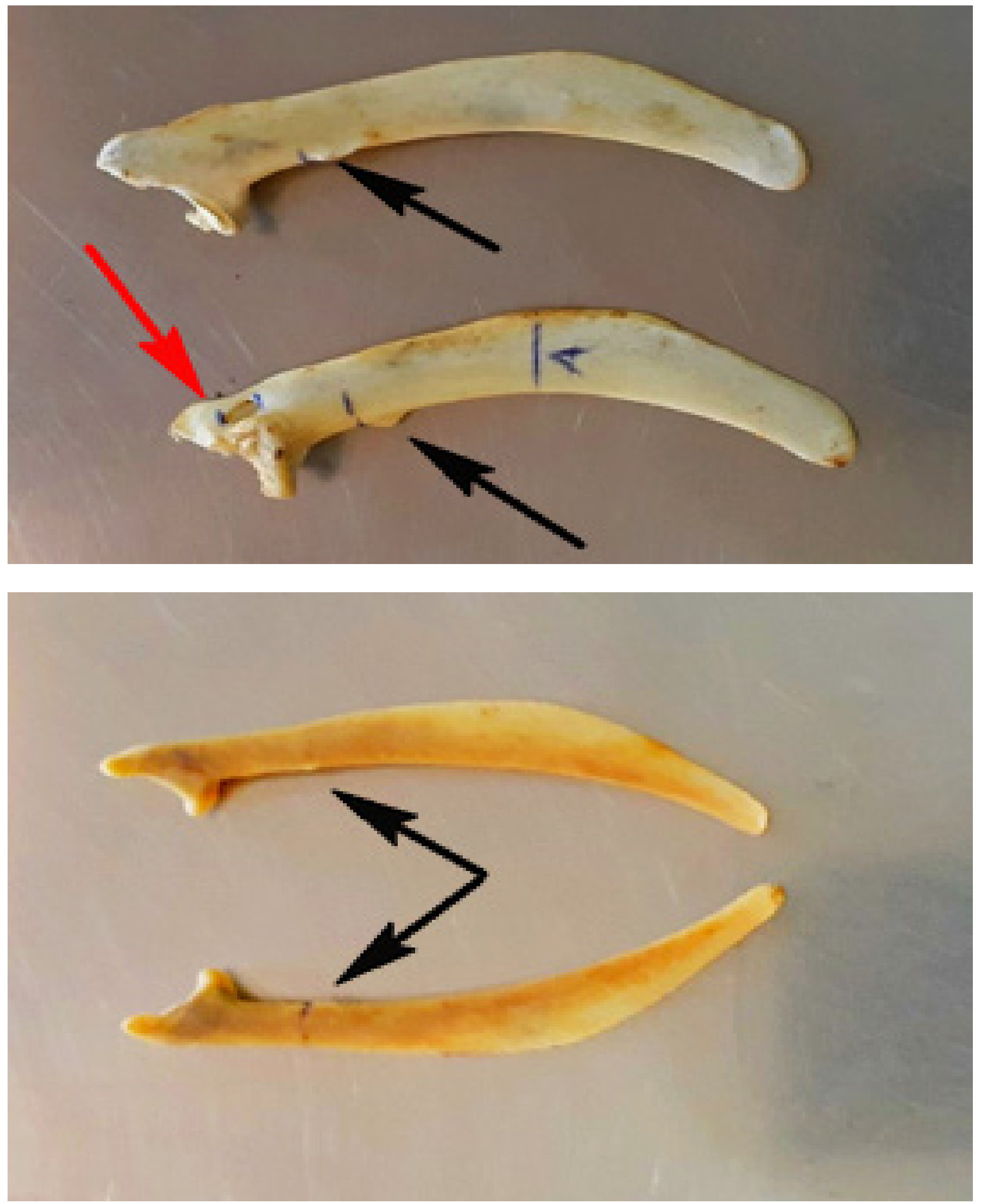

Figure 4: Photograph showing scapula of turkey $(A)$ and guinea fowl (B) with pneumatic foramen in turkey (red arrow) and point of protrusion (black arrow) and B without pneumatic foramen.

Citation: Bello Abdulrahman* and Aisha Yusuf. Comparative Osteometric Study of Some Selected Bones of Local Domestic Turkey and Guinea Fowl 

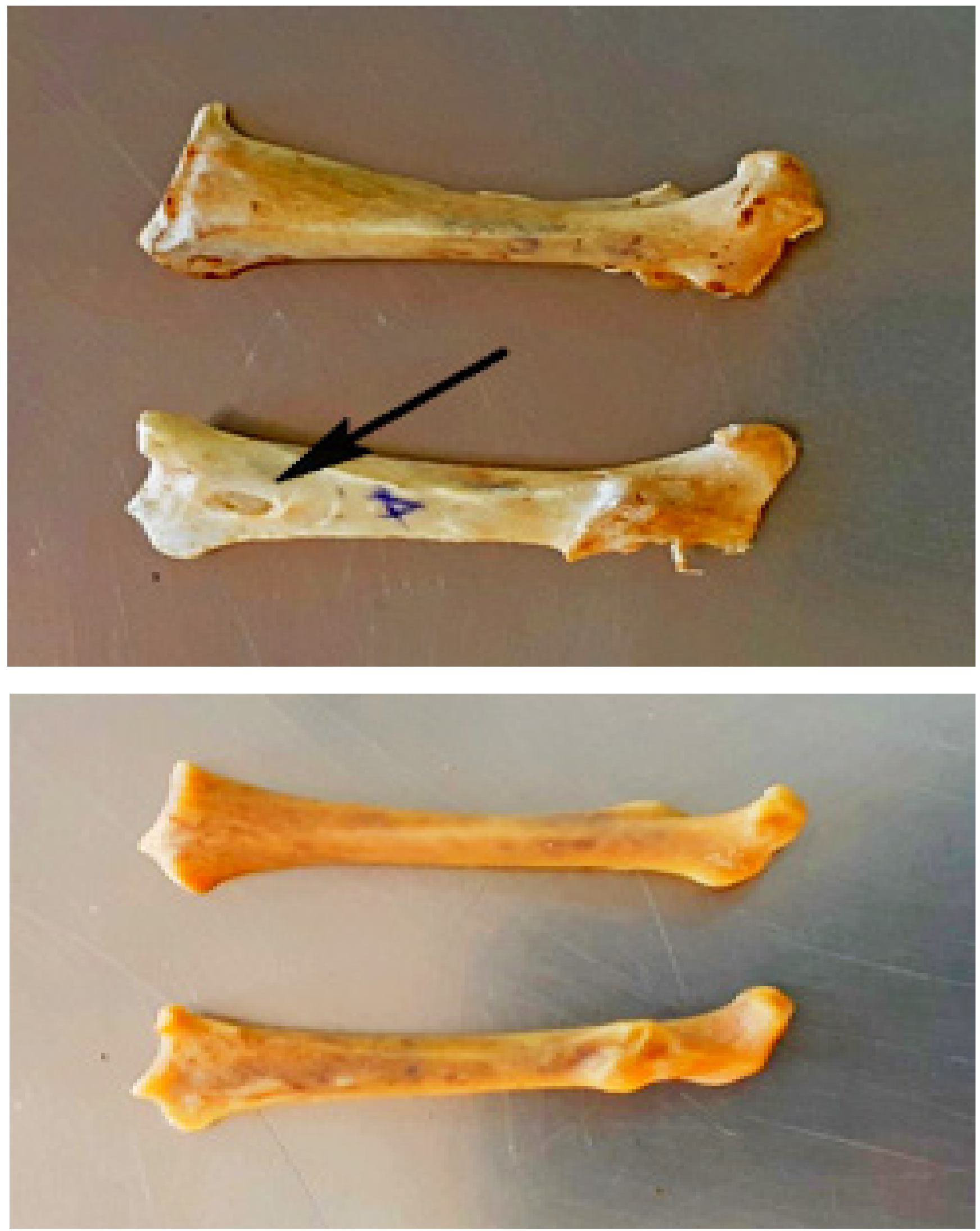

Figure 5: Photograph of coracoid of turkey (a) and guinea fowl (b) showing pneumatic foramen which is absent in that of guinea fowl.

Citation: Bello Abdulrahman* and Aisha Yusuf. Comparative Osteometric Study of Some Selected Bones of Local Domestic Turkey and Guinea Fowl

Op Acc J Bio Sci \& Res 7(1)-2021. 
The results from the study of the morphometry and biometric of selected bones of both adult turkey and guinea fowl are reported below.

After gross comparison of the selected bones from the turkey and guinea fowl (tibiotarsus, coracoid, scapula, and the furcular) the following observations were made and differences noticed concerning the furcular;

The furcular of turkeys was found to be clearly triangular in shape and both clavicles are flattened with an inverted groove at the medial side. The inter clavicle is pointed ventrally (Figures 1-5). The furcular of guinea fowls is slightly triangular in shape but both clavicles are curved in a convex manner cranially. The edges at the proximal part tapers and the inter-clavicle are bilaterally flattened.

\section{Biometric Study}

\section{Discussion}

The study revealed that most studies carried out that involve preparation and mounting of skeleton of avian species used water and heat maceration and use of chemicals such as sodium perforate. The preparation involves skinning, removal of the skin completely, removal of viscera and other soft organs before removal of muscles close to their attachment and insertion into the bones and cartilages, disarticulation and cleaning using water and a pair of forceps. Bleaching and curing to preserve the bones using either chlorine solution, hydrogen peroxide or lime water.The most fully documented historical account of skeleton production is that of the Smithsonian institute, with his formula of 72-hour hot water soaking, brushing, and the use of benzene, which has proven to be highly toxic.

The assemblage of avian skeleton involves consulting a diagram of the said avian anatomy as done in this study to ensure proper assemblage of the skeleton. Snyder, Burdi, and Gaul introduced a method of skeletal preparation that involved a quick acting formula they named anti- forming, prepared by combining sodium carbonate and bleaching powder. The authors note that other effective means are time consuming. They state that the five-step method of maceration, cleaning, degreasing, bleaching, and fixing as well as the use of domestic beetles are, in effect, not necessary. Synder notes that hydrogen peroxide and potassium hydroxide are especially useful for bones that may crack or degrade from repeated boiling and scraping, such as skull and scapula. Another method discussed that may help to avoid decalcification is macerating uncovered in clear water for a few days to weeks, followed by immersion in a detergent solution and simmered. [8].
Detergent maceration makes use of the enzymes present in the cleaning agent, and an increased speed of maceration and removal of bad smell have been observed. However, key here is that the exact composition of commercial detergents is often proprietary and not directly available. Besides various kinds of enzymes, the detergents also contain ten sides, builders (inorganic complexing agents), additives, bleaching agents and corrosion inhibitors. The aggressive mixture in detergents may cause damage to specimens and decalcification, softening and transparency of detergent-macerated bones. [9].

Yin warned of the adverse effects of enzymatic maceration on hardness of bones, and a year later [9 -20] applied various concentrations of lipase and protease, with successful results reported. Having said that, the materials and methods of four works reviewed associate in a similar mindset as each experiment builds on those whose research came before. Each scientist modifies previous works. Reducing bone modifications as well as increasing potential genetic material have become primary goals. While summary reviews are enumerated, the one point that all agree on is the negative effect of bleaching with sodium hypochlorite. All caution against its use, warning that resultant bone will be flanky and at times crumble quickly to dust. They instead suggest hydrogen peroxide or potassium hydroxide, which was used during this study [21-32].

\section{Conclusion}

The study revealed that the measured parameters have been individually evaluated for both left and right sides of the turkey and guinea fowl using two replications per treatment. The data were analyzed using Duncan system grouping and mixed procedure of statistical analysis system. The significant differences between means were detected using Duncan's multiple range tests [23-41]. The standard error of mean is set at $P<0.05$. Mounting of avian skeleton is possible but requires the use of an aged (old) bird for the betterment of necessary anatomical features. Comparative anatomical features such as foramina, crest, depressions, pneumatization, and ridges might be seen in some species and not seen in others. The most recommended flesh removal method is the maceration technique and the use of hydrogen peroxide and potassium hydroxide instead of sodium hypochlorite which is known to weaken the bone and make it flanky.

\section{Recommendation}

The following recommendations were made for future research purposes. The need to use plastic models in the production of skeletal elements in enhancing veterinary anatomical teachings. Comparative analysis should be done

Citation: Bello Abdulrahman* and Aisha Yusuf. Comparative Osteometric Study of Some Selected Bones of Local Domestic Turkey and Guinea Fowl

Op Acc J Bio Sci \& Res 7(1)-2021.

DOI: 10.46718/JBGSR.2021.07.000182 
on different flesh removal techniques in order to know which is more efficient and the use of different chemicals to ensure the specimen remain intact. Comparative analysis between breeds of local turkey, local chicken and guinea fowl should be done to see if there are differences in the anatomical features. Comparative analysis should be done on both sexes of the turkey breed of a given age. The use of other measuring and biometrical equipment's should be used when carrying out further research.

\section{References}

1. Lynch PJ (1993) AvianStructureandFunction.1st edition. New haven, Yale University press.

2. Getty R (1975) Sisson and Grossman's the Anatomy of the Domestic Animals. Vol II,5th edition. W.B.Saunder's company, Philadelphia 2095.

3. Bemis WE, Hilton EJ, Brown B, Arundel R, Richmond AM, et al. (2004) Methods forpreparingdry, partially articulated skeletons of osteichthyans, with notes on making ridge wood dissections of the cranial skeleton. Copeia 3: 603-609.

4. Ann Burke, Alan Feduccia (1997) Developmental Patterns and the Identification of Homologies in the Avian Hand. Journal of Science 278: 666-668.

5. Ogundipe SO, Sanni SA (2002) Economic of poultry production in Nigeria. In: J.O. Gefu, I.A. Adeyinka and A.A Sekoni. A training manual on national training workshops on poultry production in Nigeria. National Institute for Animal Production Research Institute (NAPRI), Ahmadu Bello University, Zaria, Nigeria 32(1): 27-45

6. Crowe TM, Bowie RCK, Bloomer P, Mandiwana TG, Hedderson TAJ, et al. (2006) Phylogenetics, biogeography and classification of and character volitional game birds (Aves Galliformes).

7. Madge S, Mcgowen P, Kirwan G (2002) Pheasants, partridges and grouse; aguideto the pheasants, partridges, quails, grouse, guinea fowl, buttonquails and sandgrouse of the world.

8. Stephens MD BJ (1979) A Simple Method for Preparing Human Skeletal Material for Forensic Examination. Journal of Forensic Science 24(3): 660-662.

9. Simonsen KP, Rasmussen AR, Mathisen P, Petersen H, Borup F (2011) A Fast Preparation of keletal Materials Using Enzyme Maceration .Journal of forensic sciences 56(2): 480-484.

10. Acker D (1971) Animal science and industry. 2nd edition. Prentice Hall Inc. Englewood Cliffs, New Jersey.

11. Alan C, Serjeantson D (1996) A manual for the identification of bird bones from archaeological sites. Archetypepublications, London.

12. Al-Sadis S (2012) Comparative morphometric study of shank bone in the tom (Meleagris gallopavo) and localcock (Gallus banikaval). Iraqi Journal Veterinary Science 26: 57-64.

13. Arismendi J, Baker L, Matteson K, (2004) Effects of processing techniques on the forensic DNA analysis of human skeletal remains. Journal of forensic sciences Issue 49: 930-934.

14. Barnikol A(1952) Morphology of Nervustrigeminusin birds with special attention on Accipitridae, Cathartidae, Striges, Passeriformes. Journal of cognitive zoology 157: 285-332.

15. Emmah SA, (1997) Economic Analysis of Turkey Production in Kaduna and Zaria Towns of Kaduna State, Nigeria. PhD thesis.
Ahmadu Bello University.

16. Hangay George, Michael Dingley (1985) Biological museum methods. Sydney Academic Press.

17. HertelF(1994) feeding morphology within past and present vulture assemblages. Ecology 75: 1074-1084

18. Indu VR, Lucy KM, Sreeranjini AR, Maya S Ashok N, Sayam KV (2012) A comparative study on the pectoral girdle of green winged macaw and pea hen. Journal of veterinary anatomy and animal sciences 43: 56-58

19. Ironkwe MO, Akinola LF (2010) Profitability of Turkey Production in Ahead East Local Government Area of Rivers State, Nigeria. Continental Journal of Agricultural Science 4: 38-41.

20. Jayachitra S. Kannan TA, Sivgnanam S, Geetha R (2013) A fast method of assembling a full skeleton. Asian Journal of Science and Technology 4(5): 86- 87.

21. John MA, Choudhury AR, Khan M, Ahmed K, Baba MA, et al. (2017) Comparative anatomical studies on shoulder girdle of pigeon hawk and kite. Indian journal of veterinary anatomy 29(1): 25- 28.

22. Kamal sarma, Jasvinder Singh Sasan, Shalini Suri (2018) Gross anatomy and biometry on tibiotarsus, fibula and tars metatarsus of Indian eagle owl (Bubo Bengalensis). Animal Medical Research. 1:123-127.

23. Lavanya C, Jayachitra S, Iniyah K, Balasundaram K (2017) Comparative anatomy of os coxae in guinea fowl and pigeon. International journal of current microbiology and Applied sciences 6(9): 3655- 3659.

24. MaheenNazir, Bashir Ahmed Shah, Shaheen Shahdad, Basit Aslam, Rabiya Amin (2018) Scapular measurements and indices, An observational study at GMC Srinagar Kashmir. International Journal of Current Research 10(3): 67125-67128.

25. Maikasuwa MA, Ala AL, Baba MD, (2014) Economic analysis of turkey production in Zuru emirates Kebbi State. International Journal of Modern research and reviews2 (7): 229-230.

26. Mairs S, Swift B, Rutty GN (2004) Detergent: An Alternative Approach to Traditional Bone Cleaning Methods for Forensic Practice.TheAmerican journal of forensic medicine and pathology 25(4): 276-284.

27. Mann, Robert W, Hugh E, Berryman (2012) A Method of Defleshing Human Remains Using Household Bleach. Journal of forensics sciences 57(2): 440-42.

28. Musa MT (2015) Evaluation of rapid and efficient method for preparation of skeletons for rabbit and goose. Bangladesh Journal of Veterinary Medicine 13(2): 27-31.

29. Warren MW, Walsh-Haney HA, Freas 1 (2015) The Forensics Anthropology Laboratory, p. 65-93.

30. Nawrocki SP (1997) cleaningbones. University of Indianapolis archeology and forensics laboratory p. 1-4.

31. Neves WA, Mark H, Maria MM, Okumura RG, Levy F, et al. (2005) A New Early Holocene human skeleton from Brazil:Implications for the settlement of the new world.Journal of human evolution 48: 403-414.

32. Nwagu BI (2002) Production and management of indigenous poultry species. Training manual, National Animal Production Research Institute (NAPRI), Federal ministry of agriculture and rural development, Ahmadu Bello University (ABU) Zaria.

33. Ogugua AE, Ukoha UU, Okafor J, Tochukwu GC (2012) World Journal of life science and medical research. 2: 39

Citation: Bello Abdulrahman* and Aisha Yusuf. Comparative Osteometric Study of Some Selected Bones of Local Domestic Turkey and Guinea Fowl 
34. Oluyemi JA, Roberts SA (2000) Poultry production in warm wet climates. 2nd edition. Ibadan, Spectrum Books Ltd.244.

35. Onwuama KT, Salami OS, Ali M, Nzalak JO (2012) Effect of Different Methods of Bone Preparation on the Skeleton of the African Giant Pouched Rat (Cricetomysgambianus) 30(2): 425427.

36. Peter B, John S, Edwards A, (2012) The science of cooking. Food science technology publication.

37. Powell, Whittow (2000) Zoo animal and wild life immobilization and anesthesia, Wiley publications.

38. Raghavan. D (1964) Anatomy of an ox with comparative notes on the horse, dogs and fowl .Indian council of Agricultural Research ,New Delhi.

39. Resk HM (2015) Anatomical investigation on the appendicular skeleton of the cattleegret, Journal of Experimental Clinical Anatomy 14(1): 5-12.

40. Robert W, Mann (2012) A method for defleshing human remains using house hold bleach. Journal of forensic science 57(2): 44042.

41. Sanni SA, Ogundipe SO (2005) Economics of some modules of poultry production in Kaduna State, Nigeria. Nigerian Journal of Animal Production 32(1): 102-107.

*Corresponding author: Bello Abdulrahman, Email: abccrcfge28@gmail.com

Next Submission with BGSR follows:

- Rapid Peer Review

- Reprints for Original Copy

- E-Prints Availability

- Below URL for auxiliary Submission Link: https://biogenericpublishers.com/submit-manuscript/ 